\title{
VISUALISATION IN EDUCATION: SOME TRENDS IN TEACHING GEOGRAPHY
}

\author{
Igor Vrhunec \\ Ketteja in Murna Basic school, Ljubljana, Slovenia
}

\begin{abstract}
The development of ITC has enabled more diverse approaches to teaching. The internet has become an important source for the pupils as well as the teachers. There are computers and projectors in the classrooms, the teachers and the pupils can access the information and many useful programmes free of charge through the internet. Power Point presentations have slowly been losing its appeal mainly because of being too static. The pupils nowadays are motivated by dynamic, information- packed and interesting lessons. This is achieved by using computer presentations where the pupils participate actively.

The programme that is being used in such lessons is going to be presented in this article. This programme enables the formation of multimedia and interesting elements.
\end{abstract}

Key words: Prezitool, presentation, motivation, geography teaching, primary school.

\section{Introduction}

Observing nature is the essential part of geography. This can be done by using different kinds of projections. With their help the pupils can observe parts of the landscape, volcanic eruptions, earthquakes and other natural processes. In these ways geography lessons have become dynamic, the pupils participate actively by employing sight and hearing, they can be creative and thus reach the aims of the lessons faster. According to Brinovec (2004), geography lessons should be perceived as a combination of sight and hearing but with the emphasis on sight.

Many different methods are used for teaching geography. According to one of them the pupils receive their knowledge by listening to the teachers' lectures. The teachers gives explanations, answers the pupils' questions and monitors their work. The drawback of this method is the fact that pupils become passive listeners. The question that arises is this: can this method be combined with the use of ICT in order to make the lessons dynamic, to engage the pupils' senses and in this way create a multisensory experience?

This question has occurred when it was discovered that Power point presentations are no longer challenging enough to engage the pupils. While using Prezi Tools older teaching methods can be applied together with more modern ones in order to make the lessons more dynamic.

\section{Prezi as a Teaching Tool}

Prezi Tools are intended for presentations and is becoming a counterpoint to Power Point. With the help of the photos, films and key words, Prezi enables the teachers to create very dynamic lessons and thus help the pupils to memorize and learn more about my subject. Prezi can be found at http://prezi.com/. It can be used free of charge, one only has to register. The instructions are presented as a short animated film and in the form of ques- 
tions and answers. In this way it is easily accessible to more inexperienced teachers. There are quite a lot of examples and suggestions for lessons on YouTube.

With Prezi, the lessons easily become multipresentable. The most important advantages of Prezi are:

- No space limits

- Texts are easily edited and can be moved around

- Photos, films, texts from the teachers' archives or the internet can easily be inserted

- Different signs can be inserted

- Parts of the pre-existent Power Point presentation can be inserted

- The important parts of the texts can be brought closer and enlarged

- Prezi can be used with the interactive board.

There are plenty of other options at Prezi. Its great advantage is working in a cloud.

\section{An Example of a Geography Lesson: Volcanoes and Earthquakes}

The aim of geography lessons nowadays is to motivate the pupils to find the quickest ways to get, use and analyze geographical information. In order to do this they have to be presented with statistic or photographic material (Brinovec, 2004).

Prezi Tools enable me to follow the didactic principles of geography. The lessons have become more dynamical, the pupils have become active observers, the teachers' role has been gradually changing from a lecturer to a lesson organizer. Prezi Tools can be used with all methods of work, in different kinds of lessons, with all the pupils.

The pupils in the present are a part of the so-called digital generation. They are used to using computers, the internet, mobile phones and to getting information instantly (Veronek, 2010). They expect a certain degree of fun while working with computers, but they have to realize that materials cannot be used for fun only.

Although lectures have been replaced by pair- or group-work in the last decades, it is my opinion that Prezi Tools is a welcome addition to lectures. Lectures usually have a fixed structure, the teacher is a link between the lesson's content, the methods of teaching and the pupils. The advantage of Prezi Tools is its ability to make a lecture more interesting and dynamic, the pupils co-operate with each other, the multimedia materials enable them to be active in their observations.

I am going to describe a lesson in the 7 th grade. The theme is Vulcanoes and Earthquakes. In the lesson I am going to use a lecture, later on the pupils are going to work individually. Operative goals of the lesson:

- The tectonic reasons for the occurrence of earthquakes

- To explain the activities of volcanoes

- To describe the effects of volcanic eruptions and earthquakes on human lives

- To introduce the geographical characteristics of Europe and Asia

- To revise the geographical concepts (Kolnik, Otič, Cunder, Oršič, Lilek, 2011)

The methods of projection, explanation and discussion use during this lesson. The lesson consists of the introductory motivation, the presentation of the lesson's goals, learning and revision. First, the pupils are shown a picture of an active volcano and the effects of an earthquake. In this way the lesson's goals are presented. Second, the pupils are shown a film about the movements of the lithospheric plates and the occurrence of volcanoes. The parts of a volcano are presented with the picture of a crater and the short film about lava. Next, the pupils are shown satellite pictures of Etna and Sicily, followed by a picture showing the beginnings of an earthquake. All this is upgraded by a film showing 
an earthquake in Japan and a picture showing parts of Slovenia that are threatened by earthquakes. In order to round up, the pupils are presented with ARSO website where the data about the current earthquake activities in Slovenia can be found. Finally, the evacuation procedures are revised (Vrhunec, 2014).

The picture of the section of the Earth is used for revision and the effects of volcanoes and earthquakes are also discussed by the pupils.

The experiences have shown that the pupils find this theme fascinating, so it is divided into two lessons. During the second lesson the pupils make a paper model of a volcano.

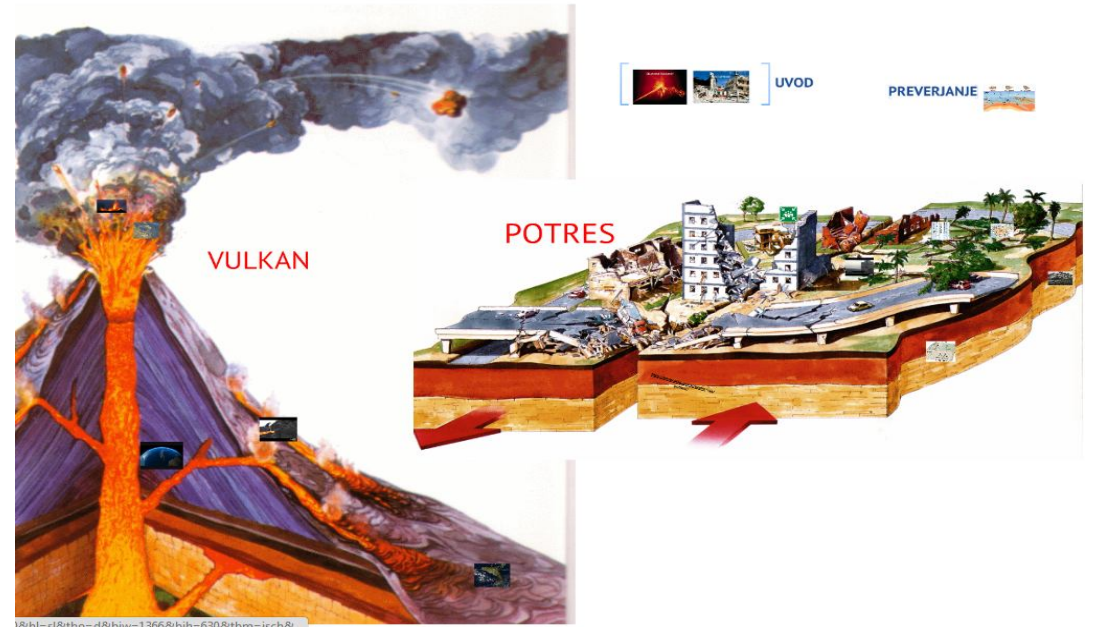

Picture 1: Introductory motivation (Vrhunec, Prezi presentation, 2014).

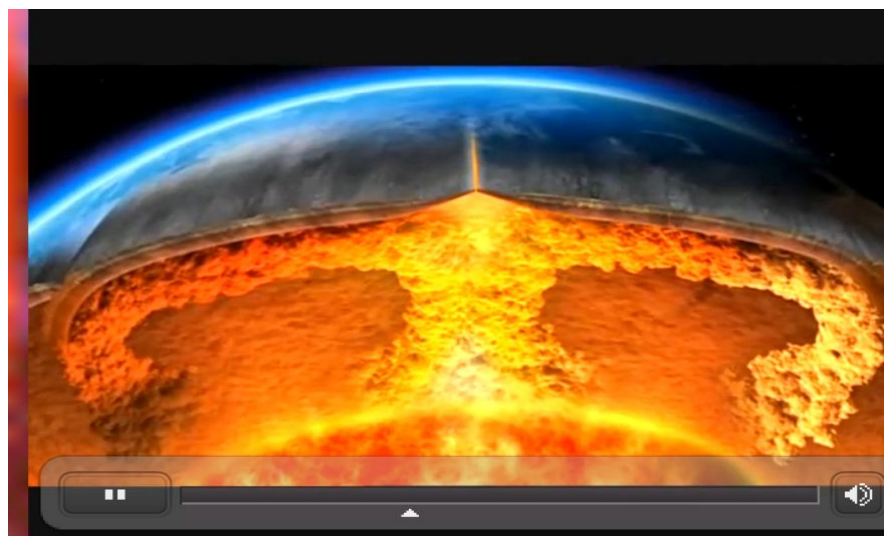

Picture 2: Learning (BBC documentary film, 2011). 


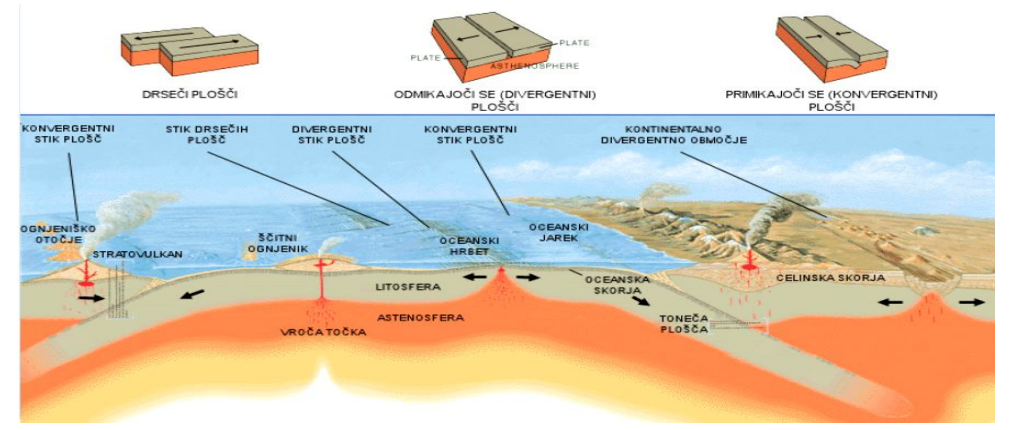

\section{Picture 3: Revising.}

The lesson has been extremely successful. The pupils have been excited, they have had no troubles in describing the pictures, they have co-operated and commented enthusiastically. They have been motivated in their work, they have also used their previous knowledge. The presentation has gone well, the enlarged parts of the text and short films have made the lesson more interesting and dynamic.

It is certain that Prezi Tool is a new concept in my work and my school. It is interesting for the pupils and it motivates them to listen and eagerly expect the next step. However, I doubt this will remain the same when/if all the teachers start using it. I also think that not all teachers will welcome Prezi since many different tools are offered by the modern technology and each teacher will be able to find the tools that is closest to his/her teaching approach.

\section{Summing-up}

Prezi is a new and attractive programme for preparing presentations at geography. It offers many ways of preparing and using materials. At the beginning, it can be quite challenging, especially if one is more familiar with Power Point. While using Prezi one must not forget the lessons' aims since they represent the guidelines for the use of the materials.

When preparing my lessons I present my own materials as multimedia. Since all the materials are in a cloud, they can easily be adapted and upgraded. With the use of the internet I also get a lot of user-friendly materials which are mostly used for introductory motivation, for learning and for revising.

By using Prezi Tools at geography one has to be creative and consequently that motivates the pupils. Pupils were motivated and active through the whole duration of the class. They followed each learning step and learned from each learning slide provided. The graphic material enabled them easier understanding of the subject matter. The pupils were very thrilled with this method of learning. They said, that this class was a different experience for them.

Furthermore, I have become more motivated as a teacher as well. Prezi Tools has been used for other kinds of presentations and I am very satisfied with it.

\section{References}

Brinovec, S. (2004). Kako poučevati geografijo, Ljubljana: Zavod Republike Slovenije za šolstvo, 31-38, 88-111. 
Kolnik, K., Otič M., Cunder K., Oršič T., Lilek D. (2011) Geografija učni načrt, Ljubljana. Minsterstvo za šolstvo in šport; Zavod za šolstvo, 10-13. Retrieved February 8,2014 from http://www.mss.gov.si/fileadmin/mss.gov.si/pageuploads/podrocje/os/ devetlet$\mathrm{ka} /$ predmeti_obvezni/Geografija_obvezni.pdf

Veronek, N. (2010). Vloga elektronske table v didaktiki geografije. Geografija v šoli, 2, 29-34.

Prezi (2014). Retrieved February 8, 2014, from https://prezi.com/support/

Prezi (2012). Retrieved February 8, 2014, from http://www.youtube.com/watch?v= Tp1iqZQH5vI

Vrhunec, I. (2014). Prezi predstavitev: Vulkani in potresi. [prezi presentation] Retrieved February 16, 2014, from http://prezi.com/m4ewh4wk181o/prezi-predstavitev-vulkani-inpotresi/

Shema tektonskih plošč [tmage] (2006). Retrieved February 8, 2014, from http://sl.wikipedia.org/wiki/Slika:Shema_tektonskih_plo\%C5\%A1\%C4\%8D.png

BBC documentary film Earth the Power of the Planet [imrge] (2011). Retrieved February 8, 2014, from http://www.youtube.com/watch?v=ryrXAGY1dmE

Received 28 January 2014; Accepted 15 March 2014

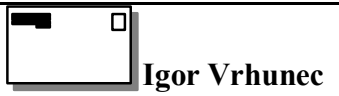

Teacher, Ketteja in Murna Basic school, Koširjeva ulica 2, 1000 Ljubljana, Slovenia.

E-mail: igor.vrhunec@guest.arnes.si 